\title{
Sustainable Tourism and Eradication of Poverty (Step): impact assessment of a tourism development program in Brazil
}

\author{
Marcelo Cortes Neri \\ Fundação Getulio Vargas \\ Wagner Lopes Soares \\ Instituto Brasileiro de Geografia e Estatística
}

\begin{abstract}
This paper aims to evaluate the social impacts of the Tourism Development Program (Prodetur) in the northeastern town of Porto Seguro, Bahia, Brazil. The method used is based on the difference in difference technique applied to the 1991 and 2000 Census microdata. The results suggest social advances following from poverty relief based on income - where the benefits are distributed, generally, in a relatively equal manner between the native and migrant population. There is a relative deterioration in the sanitary situation, which consists of a very serious problem in the mid- and long-term, whose costs are mostly borne by the native population. Therefore, maintaining the natural capital is the main aspect that distances Porto Seguro's tourism supply from the concept of sustainability. The article also relies on difference in difference estimators to assess the impacts of local public policies related to the sector.
\end{abstract}

KEY WORDS: sustainable tourism; poverty; programme evaluation; difference in difference; public policies.

Turismo Sustentável e Alivio à Pobreza (Tsap): avaliação de impacto de um programa de desenvolvimento ao turismo no Brasil.

Este artigo tem como objetivo avaliar os impactos sociais do Programa de Desenvolvimento do Turismo (Prodetur) no Nordeste no município de Porto Seguro, Brasil. O método baseia-se na técnica de diferença em diferenças e utilizamos os microdados dos Censos Demográficos de 1991 e 2000. Os resultados sugerem avanços sociais com o alívio à pobreza, sendo os benefícios distribuídos em geral de forma igualitária entre população nativa e migrante. Há uma piora relativa na questão sanitária, que se configura em um sério problema ambiental de médio e longo prazo, cujos custos são em sua maioria absorvidos pela população nativa. Conclui-se que a manutenção do capital natural é o principal problema que afasta o turismo ofertado em Porto Seguro do conceito de sustentabilidade. O artigo também reforça o uso dos estimadores de diferença em diferença como um bom método de avaliação de impactos de políticas públicas no setor.

Artigo recebido em 16 nov. 2010 e aceito em 10 maio 2011.

RAP - Rio de Janeiro 46(3):865-78, maio/jun. 2012 
Palavras-chave: turismo sustentável; pobreza; avaliação de programas; diferença em diferenças; políticas públicas.

\section{Introduction}

The tourism market is sui generis in the sense that it has an indirect or direct interaction with different markets (labor, services, assets, culture etc.). According to Brocklesby and Fisher (2003), a tourist consumer demands from the producer different types of capital (human, natural or environmental, physical, social, cultural and economic). As a result, assessing the supply and demand of these capitals, the eventual impacts on the allocation of such assets, requires a reference or conceptual framework. Besides, it also requires an analytical effort about the numerous variables that would be related to the tourism industry.

The combination of these different types of capitals generates what the present work calls tourist capital. For instance, when deciding about a destination, a tourist assesses the presence of different capital in a given place: human (good personalized service, easy communication, language, hospitability, health environment), the wildlife, physical (infrastructure, leisure, comfortable settings), cultural (music, art, costumes, religion etc.), social (poverty, drinking water, sanitation, police, security) and economic (prices, exchange rate, interest rates, and credit) (Sirakayaa and Woodside, 2005; Papatheodorou, 2001).

Another important aspect is that both the consumption and production of these goods also cause impacts on them and may enable an increase or decrease in the stocks of capitals (Northcote and Macbeth, 2006). Generally, tourist consumption brings social gains to the tourist destinations, as there are numerous impacts in the labor market, income generation and poverty reduction (Blake et al., 2008; Croes and Vanegas, 2008; Hawkins and Mann, 2007, Kakwani, Neri and Son, 2010).

Nonetheless, tourist consumption may also have negative impacts (Burns and Holden, 1995; Logar, 2009). For example, the consumption of natural assets without the necessary ecological conscience may create negative environmental externalities (Davies and Cahill, 2000; Dixon et al., 2001). Likewise, cultural interactions may detract from local culture's characteristics, which is increasingly valued by tourists worldwide (Mathieson and Wall, 1986; Yildirim et al., 2008). The growth in tourist activity combined with infrastructure problems may have more serious consequences, as an increase in slums and in the population's insecurity. New developments may cause environmental problems, changes in the landscape or in the natural capital, an increase in the unmet demand for sanitation, supply of drinking water, transport shortage, that is, consequences that may compromise the sustainability of the tourist site.

Another important point is that monetary gains from tourist activity may also not be egalitarian, with a greater intensity in the entrepreneurs' group to the detriment of the local population. The same fact occurs in the labor market, that is, a larger use of the migrant workforce to the detriment of the native population (Ministério do Turismo, 2005). 
Figure illustrates some interactions between the tourism industry and different variables. In some tourist places, a trend is that the tourism supplier disengage from local problems, generating inequality in the allocation of costs and benefits from such activity (Ministério do Turismo, 2005). In this case, costs would be transferred to society at large and the benefits would remain in the hands of the entrepreneurs, mostly migrants seeking different types of tourist capital. Only a small share of the revenue from this activity would pertain to the tourist location.

The problems with this type of tourist market model is its unsustainability. There are numerous impacts that, in their turn, would compromise the industry of tourism itself, that is, would concur to depleting the different capital stocks that enable the construction of the tourist capital. In view of this problem, a change in the concept of tourism is necessary, or better still, bringing along the sustainability element, as it is pressing to have a kind of tourism that reconciles preservation, the rational use of capitals and a better distribution of socio-economic benefits.

\section{Figure}

Tourist market and overall impacts

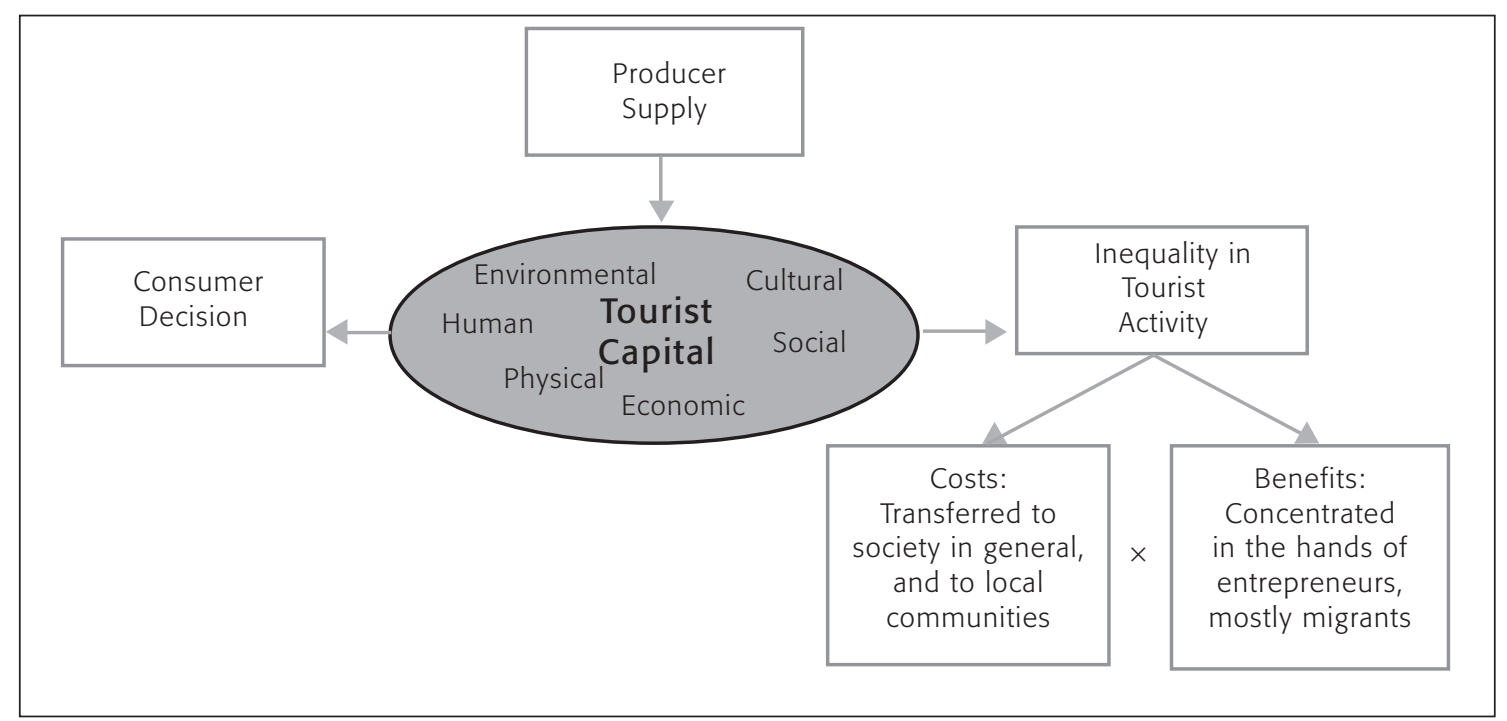

Source: Authors.

\subsection{Sustainable Tourism and Poverty Relief}

The development of tourism based on the concept of sustainability minimizes the use of resources, uncompromising the local culture and the environment and improving the infrastructure demanded by the sector (Swarbrooke, 1999). For instance, in sustainable tourism, the effects of seasonality are minimized through creative solutions of income and job generation. 
Income-generating tourist products for the minority groups and native population should be fostered, fighting inequality created by tourist activity, once its costs tend to the transferred to the local population and the benefits accrue to the entrepreneurs who, in general, are the migrant population (OMT, 2003).

These tourism sustainability proposals concur to poverty reduction as it favors the accumulation of capital in its different kinds. In other words, some sustainable tourism outputs, such as job generation and an increase in value of the local workforce, among others, work as inputs when the objective is poverty reduction. Summing it up, sustainable tourism demands a positive discrimination of less privileged social classes in the development process of tourism (Sachs, 1993).

With that in mind, places like Porto Seguro and the Brazilian northeast in general being highly attractive for tourism, with a deep social chasm reflected in income inequality and other indicators compared to the rest of the country - have a tourism profile suitable for the sustainability concept, with a direct consequence to poverty relief.

\subsubsection{Tourism and poverty relief in Brazil}

The Brazilian case, especially in the country's northeast, is a good example when thinking about sustainability and poverty relief. It has an enormous potential for tourism, albeit little explored, combined with high inequality and poverty if compared to the rest of the country. The current article shows that sustainable tourism may be a great ally in poverty reduction based on income and formal job creation in the northeast region, the poorest in Brazil. Furthermore, this paper illustrates how the difference-in-difference method, as applied to the Demographic Census microdata, may be useful to assess economic, social and environmental impacts of local development programs in tourist destinations. The paper combines results in different dimensions to evaluate the concept of sustainable tourism and poverty relief in the northeastern town of Porto Seguro.

\subsubsection{The target population and the tourism development programme}

Porto Seguro is the main city in the region of Brazil's discovery site, where the Portuguese arrived for the first time. It has a little bit more than 114 thousand inhabitants and is registered as a national historic site. Although it may have a considerable cultural and historic wealth, the main attraction for tourists from all over the world is its natural beauty. The city is currently considered one of the main tourist sites in Brazil, with a long seashore of c. 85 $\mathrm{km}$, with beautiful beaches and a lush wildlife. It also has a good hotel infrastructure and an international airport.

The Brazil's Northeast Tourism Development Program (Prodetur/NE), which was executed by the Banco do Nordeste do Brasil, in its first phase had investments in nine states of 
the Northeastern region, with a total of US\$ 625,96 million. Of this amount, around US\$ 101 million were invested in the discovery site alone, where Porto Seguro is located (Ministério do Turismo, 2005). All in all, 60\% of the resources came from the Inter-American Development Bank and the rest came from local governments, whose investment timeframe began in 1995 and ended in 1999. Nevertheless, in reality and unlike Porto Seguro, in some towns the programme ended only in 2005.

In general, investments aimed at: the strengthening of institutional structures adequate to foster and encourage sustainable tourism; an improvement in the environmental and sanitary conditions; an improvement in airports and roads; restoration and preservation of the historical heritage and an improvement in other tourist products. On the other side, such investments in infrastructure and public services in these areas of tourist expansion sought to reinforce the capacity of the Northeastern region of the country, contributing to the regional socio-economic development in the following manner (Ministério do Turismo, 2005):

i) Attract additional and better structured private tourist activities;

ii) Job and income generation;

iii) Increase in public revenue;

iv) Benefit the low income population with water, sewage and road-surfacing services.

\section{Material and methods}

The objective of this study is to assess the social impacts of Prodetur from the perspective of sustainable tourism with indirect results for poverty relief. In this sense, the impacts on different assets are assessed, among which is what we call tourist capital, to a certain extent. Aside from evaluating the stocks of different types of capital used by the tourist activity within the sustainability concept, it also sought to assess some social impacts resulting from the outputs, such as poverty reduction. We compared the objects upon which acted the program of support to tourism with other regions with a tourism potential and similar features, which public intervention did not target.

In the current paper, we use the 1991 and 2000 Census microdata, considering the availability of longitudinal municipal data for at least two periods, allowing to compare the performance between places that have undergone the intervention by some tourism support programme (treatment group — Porto Seguro) with other tourist municipalities that had not been the object of intervention during the period of the study (control groups - Aracati, Barreinhas, Cruz, Fernando de Noronha, Maragogi, Tibau do Sul). As a result, it is possible to assess the before and after status of the mentioned programme.

As mentioned before, there are many variables that can be used to assess the impact of tourism, and particularly in the Census, those which fall within the theoretical framework exposed — we have selected eight variables: three for improvements in sanitation (waste 
collection, water and sewage system); two variables for improvements in the destination of waste and sewage (if dispensed in river, lake, sea); reduction in poverty (here understood as income insufficiency <US\$2/day); increase in jobs; and increase in formal jobs (assessed through payment contributions to the Social Security System).

Although it may simplify the relations described in the theoretical framework, the analysis of these eight variables allows identifying whether the results of policies contradict the concept of sustainable tourism and poverty relief. Besides, in some cases, it is worth assessing these impacts between groups of natives and migrants with the aim of assessing the distribution of benefits between them, that is, verifying if they have been divided equally. As mentioned before, sustainability in tourism requires the reduction in inequality between native and migrant groups, which is the result of the socialization of private costs to the detriment of individual benefits.

The method is based on the difference in difference technique that compares differences in the proportions of the variables as observed in affected areas (Porto Seguro) and control areas, before and after the implementation of tourist projects, as in the case of Prodetur/NE in its first phase. With this estimator, time trends in common for both groups are eliminated and the real impact of the program can be measured (Card and Krueger, 1994; Meyer, 1995; Ravaillon, 2005).

g3 = (Treatment Gr. After intervention - Gr. Control After intervention) - (Gr. treatment before the intervention - Gr. Control before the intervention);

\section{Or, even better:}

Difference in difference $=$ (Porto Seguro2000 - Other touristic destinations 2000) (Porto Seguro1991 - Other touristic destinations1991)

Differences in differences are based on regressions with controls, where the interaction between the treatment municipality and the year reflects our measure of impact, which points out the effect of the intervention in the municipality vis à vis the remaining municipalities that had not been targeted by the tourism programme policies. The method is represented by a regression creating various dummies: $\mathrm{dB}$, which is equal to one for the treatment group individuals (Porto Seguro) and zero for the control group (other tourist destinations); and d2, which is equal to one when data refer to the second period (2000), after Prodetur I, and zero in case data refer to the before-change period (1991), we have:

$$
\mathrm{Y}=\mathrm{g} 0+\mathrm{g} 1 * \mathrm{~d} 2+\mathrm{g} 2 * \mathrm{~dB}+\mathrm{g} 3 * \mathrm{~d} 2 * \mathrm{~dB}+\text { outros fatores }
$$

Where g3 represents the difference in difference estimator, or better still, the effect of the programme on the studied variable, controlling other relevant factors.

In this paper, we will estimate eight regressions in order to verify impacts on the variables subject to evaluation that have been mentioned above. What's more, additional regres- 
sions allow evaluating the distribution of these benefits between natives and non-natives, which requires for each studied variable the estimate of other two models to represent the impact on these two population sub-groups, increasing sixteen fold the number of estimated regressions, that is, eight models for the native population and eight more for the migrant population. Therefore, in total, we estimate 24 regressions and, consequently, the same number of difference in difference estimators (g3).

The control variables of these regressions have been: sex, race (afro and non-afro), age, education, location of house (rural, non-urban area, rural area exclusively, urban area), migration (native, migrant), municipality (Aracati, Barreinhas, Cruz, Fernando de Noronha, Maragogi, Tibau do Sul), year (1991). By including the control variables, we assess Prodetur impacts on individuals with identical features relating to the sex, race, age, education, etc.

In the present paper, we will only show the difference in difference estimators, here represented by their odds ratio, which gives a measure of the impact on the studied variable. The complete models, that is, 24 regressions can be obtained in the CPS/FGV site in the research "Panorama dos Destinos Turísticos".

A positive aspect of this technique is that the period in question comprehends periods of macroeconomic instability and stability, which somehow impacts directly the data used between these two years. This makes such technique even more attractive because it compares the changes between these municipalities in the period, considering that all (treatment and control) groups have experienced both the turbulences and calms of the macroeconomic environment through the decade.

\section{Results}

Table brings the odds ratio obtained through the difference in difference estimator. Through them, we may assess indirectly the impact on indicators in the period in question in Porto Seguro, by comparing the results with other municipalities' that did not undergo the intervention. Likewise, the table brings the odds ratio of the difference in difference estimator for the native and migrant groups, allowing an assessment about the distribution of the programme's impact on these two population sub-groups.

Generally, during the period in question, access to public provision of water and waste collection in Porto Seguro is relatively inferior to the control municipalities, which is not true when assessing the chances of accessing waste collection compared to Tibau do Sul, as it is $15 \%$ larger for the former, with a relative improvement in access for the native sub-groups. This relative improvement in the access to waste collection and water by natives groups in Porto Seguro is only true when comparing it to Tibau do Sul; Porto Seguro migrants have better access to these services when compared to non migrants. For instance, when compared to Maragogi, access to water in the period analyzed in Porto Seguro is $38 \%$ smaller, whereas for the native population this proportion is $49 \%$ smaller. 
In terms of the access to the public sewage system, although the odds ratio is larger than one, meaning a relative improvement in Porto Seguro, it has not been significant, and we are not able to statistically assess the impact. In such case, the odds ratio is significant only when evaluating the regression for the native population sub-group, where the chances of accessing the public sewage system in Porto Seguro were smaller in period in relation to the municipalities that have not been in the programme. The same happens with the final disposal of waste and sewage because they are statistically significant when comparing Barreirinhas and Maragogi. When assessing the chances of Porto Seguro and Barreirinhas in what concerns the final disposal of waste in the water, they are higher for Porto Seguro, interestingly. Nonetheless, much of this result is due to the migrant population, bearing in mind that, for the native population alone, the chances of destination of this waste are $55 \%$ smaller in Porto Seguro. Similarly, chances are $90 \%$ smaller for Porto Seguro in relation to Maragogi, whereas if evaluating only the migrant groups, these chances are still smaller, although in a reduced proportion (49\% smaller).

\section{Table}

Difference in Difference Estimator (Odds ratio): Porto Seguro Treatment municipalities $2000 \times$ control municipalities in 1991

\begin{tabular}{|c|c|c|c|c|c|c|c|c|c|c|c|c|c|c|c|}
\hline municipalities & 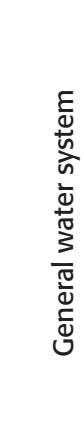 & & 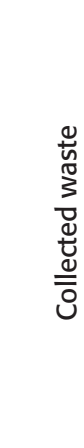 & & 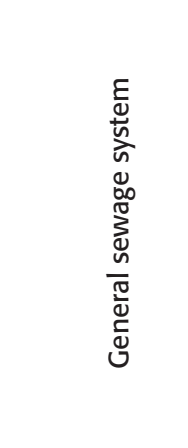 & & 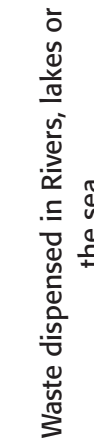 & 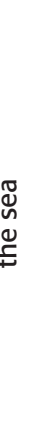 & 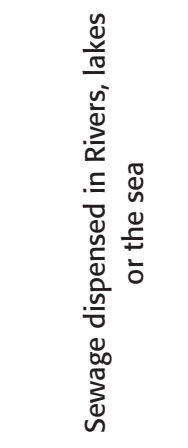 & 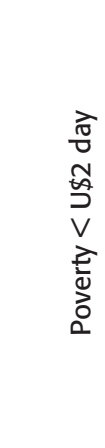 & & 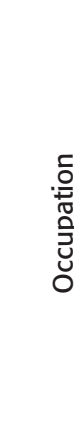 & & 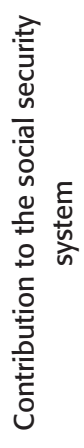 & \\
\hline \multicolumn{16}{|l|}{ Control } \\
\hline \multicolumn{16}{|l|}{ Aracati } \\
\hline Total & 0,81 & $* *$ & 1,01 & ** & 25,222 & & 0,00 & & 12729653118 & 0,30 & $* *$ & 1,66 & $* *$ & 1,01 & \\
\hline Native & 0,79 & $* *$ & 1,00 & & 0,44 & $* *$ & 0,00 & & 53002239271 & 0,24 & $* *$ & 1,73 & $* *$ & 1,11 & $* *$ \\
\hline Migrant & 0,81 & $* *$ & 1,48 & $* *$ & 33,54 & & 0,27 & & 3,82 & 0,37 & $* *$ & 1,37 & $* *$ & 1,11 & \\
\hline \multicolumn{16}{|l|}{ Barreirinhas } \\
\hline Total & 0,74 & $* *$ & 0,03 & $* *$ & 84043469838 & & 1,83 & $* *$ & 0,00 & 0,13 & $* *$ & 1,01 & & 1,09 & $* *$ \\
\hline Native & 0,65 & $* *$ & 0,03 & $* *$ & 0,92 & $* *$ & 0,45 & $* *$ & 0,00 & 0,10 & $* *$ & 1,02 & & 1,18 & $* *$ \\
\hline Migrant & 0,75 & $* *$ & 0,06 & $* *$ & 19432252061 & & 2,50 & $* *$ & 5,03 & 0,53 & $* *$ & 0,94 & & 1,33 & $* *$ \\
\hline
\end{tabular}




\begin{tabular}{|c|c|c|c|c|c|c|c|c|c|c|c|c|c|c|}
\hline municipalities & 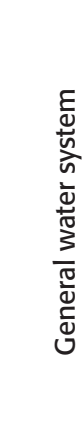 & & 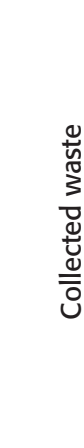 & & 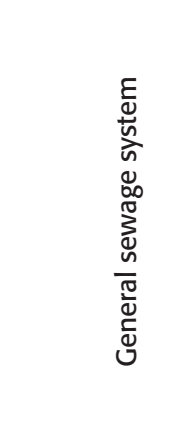 & & 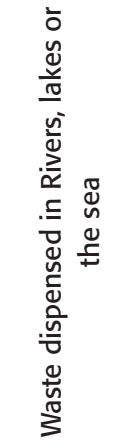 & 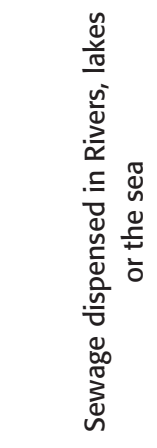 & 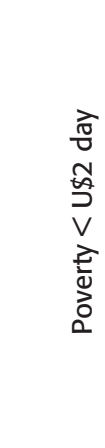 & & 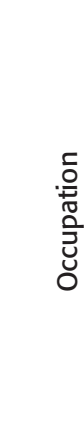 & & 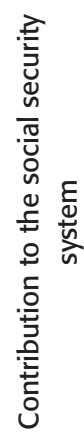 & \\
\hline \multicolumn{15}{|l|}{ Cruz } \\
\hline Total & 0,00 & & 0,23 & & 17,887 & & 0,00 & 10,10 & 0,33 & $* *$ & 1,66 & $* *$ & 0,65 & ** \\
\hline Native & 0,00 & & 0,18 & $* *$ & 0,58 & $* *$ & 0,00 & 31,65 & 0,26 & $* *$ & 1,71 & $* *$ & 0,57 & ** \\
\hline Migrant & 0,00 & & 1,00 & & 13,46 & & 0,00 & 4,73 & 0,45 & $* *$ & 1,46 & $* *$ & 1,49 & $* *$ \\
\hline \multicolumn{15}{|l|}{ Maragogi } \\
\hline Total & 0,62 & $* *$ & 0,17 & $* *$ & 21,398 & & $0,10 \quad * *$ & 9,36 & 0,20 & $* *$ & 1,71 & $* *$ & 1,64 & ** \\
\hline Native & 0,51 & $* *$ & 0,13 & $* *$ & 0,33 & $* *$ & $0,07 \quad * *$ & 34,59 & 0,17 & $* *$ & 1,78 & $* *$ & 1,65 & ** \\
\hline Migrant & 0,63 & $* *$ & 0,90 & & 150,26 & & 0,51 & 6,13 & 0,20 & $* *$ & 1,29 & $* *$ & 1,89 & ** \\
\hline \multicolumn{15}{|l|}{ Tibau do Sul } \\
\hline Total & 0,08 & $* *$ & 1,15 & $* *$ & 257,624 & & 0,00 & 8,03 & 0,96 & & 1,06 & & 0,95 & \\
\hline Native & 0,06 & $* *$ & 1,33 & $* *$ & 0,30 & $* *$ & 0,00 & 27,29 & 0,74 & $* *$ & 1,25 & $* *$ & 0,92 & \\
\hline Migrant & 0,08 & $* *$ & 1,23 & & 88,17 & & 0,29 & 4,82 & 1,21 & & 0,51 & $* *$ & 0,94 & \\
\hline \multicolumn{15}{|l|}{ Fernando de } \\
\hline \multicolumn{15}{|l|}{ Noronha } \\
\hline Total & 0,88 & & 0,28 & & 58905482219 & & 0,31 & 9,56 & 2,43 & $* *$ & 1,34 & $* *$ & 3,54 & ** \\
\hline Native & 0,63 & $* *$ & 0,38 & $* *$ & 0,59 & $* *$ & 0,49 & 38,08 & 1,33 & & 1,54 & $* *$ & 5,31 & ** \\
\hline Migrant & 0,90 & & 0,29 & $* *$ & 22531946870 & & 0,23 & 3,37 & 8,13 & $* *$ & 1,07 & & 2,49 & ** \\
\hline
\end{tabular}

Control variables: sexo, race (afro and non), age, education, household profiel (rural non-urban, exlusively rural, urban) Migration (Native, Migrant), municipality (Aracati, Barreirinhas, Cruz, Fernando de Noronha, Maragogi, Tibau do Sul), Ano (1991) Source: CPS based on 1991 \& 2000 Census. In total, 24 regressions were estimated and can be obtained in the site: <www.fgv.com. $\mathrm{br} / \mathrm{cps}>$ in the research entitled "panorama dos destinos turísticos".

** significant at $95 \%$

Source: Authors.

Between 1991 and 2000, chances of occupation grew more in Porto Seguro when compared to chances in the other control municipalities, suggesting an impact of the tourism programme on this municipality. Chances are $66 \%$ higher in Porto Seguro in relation to Aracati, 
and 71\% and 34\% higher in Maragogi and Fernando de Noronha, respectively. In relation to Barreirinhas and Tibau do Sul, the effects on occupation gains in Porto Seguro are a little more discreet, once chances increase at $1 \%$ and $5 \%$, respectively. What's more, this behaviour is similar in the formal employment market, considering that changes in the chances of payment contributions to the social security in the period are higher in Porto Seguro, when compared to the remaining municipalities, except for Cruz and Tibau do Sul. It must be noted that the chances of making payments to social security in Porto Seguro are $253 \%$ higher than the one found in Fernando de Noronha, suggesting a high degree of informality in the job in this last tourist destination.

A corollary of these results is the proportion of poor people, which decreases in Porto Seguro when compared to the other municipalities, except for Fernando de Noronha. That is, a better relative position of Porto Seguro's poverty reduction efforts in the period can be justified by the best relative position in the creation of jobs.

In relation to the distribution of these benefits between natives and non natives, generally, natives of Porto Seguro are in a better position relative to the migrants, since chances of occupation compared to control cities are higher for the former in relation to the migrant population. As it was expected, this pattern also happens when evaluating the chances of finding people with an income below US\$2/day. For example, in relation to a native resident in Cruz, a person born in Porto Seguro has 61\% more chance of being occupied and 74\% less chance of being in poverty, whereas these data are 46\% higher and 55\% lower, respectively, when assessing only the migrant population. The trend is generally felt.

On the other hand, this kind of employment has a high degree of informality, considering that Porto Seguro migrants have almost always had greater chances of contributing to the Social Security system compared to the non-migrants from this same municipality. One example is to compare Porto Seguro to Cruz because the chances of contributing to the Social Security System are 35\% smaller in Porto Seguro, while by assessing migrants alone in the same town, the chances become $49 \%$ higher when compared to Cruz.

\section{Conclusion}

The experiment above is an excellent tool to assess the impacts of public policy programs. In the tourism sector, we could even argue that this method is more efficient in view of the many variables that need to be assessed. In the present paper, we clearly see a pattern in relation to Porto Seguro's performance for the variables used here to capture the effects of investments in tourism and its consequences, that is, its costs and benefits for the stock of tourist capital of that region. Besides, the empirical exercise enables the assessment of such process through a sustainability point of view by evaluating indicators of the environment, income, poverty and its distribution among migrants and non-migrants.

Overall, it may be said that the plan for the development of tourism in the Porto Seguro region resulted in well delineated costs and benefits. In terms of costs: problems in the town 
refer to its urban infrastructure, more precisely, aspects relating to sanitation, which represent a serious environmental problem in the medium and long terms. Additionally, the problem is even worse for natives, who have the lowest chances of accessing water, the sewage system and waste collection.

Curiously, Prodetur in its first phase prioritized investments on sanitation; hence this result is consistent with the tourist overflow into town deriving from the tourism boom that consisted of an increase in the real estate market and the hotel industry. In relation to this last point, in the same decade the municipality become third in Brazil in terms of the number of hotel rooms, surpassed only by Rio de Janeiro and São Paulo. There are around 35 thousand rooms distributed across 600 hotels and inns. Between 1993 and 1998, the Discovery Coast's number of visitants increased $48 \%$ and tourism revenue, $112 \%$; while the average world growth of tourist flow remained around 25\% for the same period (Mendonça Júnior, Garrido e Vasconcellos, 2001).

The results found are worrying because the greatest assets are environmental attributes, mainly beaches, which require greater sanitary control of sewage and waste being disposed in rivers, lakes or the sea with direct impacts for tourism. Another sanitation issue refers to diseases' vector control, which is a necessary condition to keep a healthy and disease-free environment, as an unhealthy setting will hardly ensure tourism returns to the municipality. In places with a deficient sanitary infrastructure, the presence of health-threatening pathogens is markedly bigger and may cause serious diseases, such as acute diarrhea, more harmful in kids, intestine parasithosis, cholera, among others.

Results show that tourism has grown in Porto Seguro, albeit in an unsustainable manner given the depletion of its tourist capital. It is known that ecotourism expands the frontier of tourism, as nature is unique to each place and cannot be copied. Nevertheless, gains from this type of tourism directly depend on its conservation, which rests on a sound management of natural capital (Costanza and Daly, 1992).

Nonetheless, the fact that the 2000 Census data did not capture all of Prodetur I investments in sanitation is a relief in the sense that a share of the works may have been concluded after the Census coverage period, suggesting that these results should be seen carefully. Another point that should be emphasized that the data discussed are not so recent (1991 and 2000), but with the prospect of the Brazilian national census of 2010, new sequence analysis may give to this study, revealing the path followed in this first decade of the millennium.

When assessing the benefits, there is a positive relation with indicators of occupation, formality, income and poverty. Overall, the impacts on these indicators have been significant when compared to those municipalities that have not been targeted by Prodetur I. In this case, such results open up different opportunities and boost many enterprises, hitherto little structured and accredited. The presence in the Northeast of the biggest microcredit program in Brazil called CrediAmigo may boost the whole tourism industry for microenterprises (Neri, 2008).

Among the main inputs for the tourist sector is the workforce that exists in many activities in the industry: hotel, travel agencies, entertainment, restaurants, retail, etc. Tourism opens up numerous opportunities. While in the car industry, US\$ 350 thousand are necessary 
to generate one single job, in tourism, only US\$20 thousand are necessary to ensure a job in a hotel and 5 thousand dollars, for a job in a restaurant (Arbache, 2001).

In this case, data reveal that both employment and formality have grown in Porto Seguro in the period in question, compared to Prodetur non-targeted towns. What's more, it does not suggest a relative deterioration of the native vis à vis migrants; on the contrary, it shows distinct gains in favour of natives - which places this municipality in the right track for tourism sustainability, as described in this article.

In what concerns poverty relief, it is known that tourism organizes itself and creates consumption in the very place of production, conditioning its contribution to the reduction of poverty. Nonetheless, the potential of tourism to alleviate poverty will directly depend on the adoption of principles and actions that place the excluded groups as agents of these activities. By assessing the impacts of investments made in Porto Seguro, it is possible to see that aspects related to the growth of tourism and the division of benefits lead to the relief and reduction of poverty in the region - resulting from a kind of tourism that rests on sustainability.

Nonetheless, the path to sustainability requires something else, something which has not been significantly improved as the current data showed. The bottleneck in the sanitary infrastructure in the municipality jeopardizes all Prodetur efforts towards an outcome that paves the way for sustainable tourism - hence, it is indispensable to focus on this issue in the future public interventions in the sector.

\section{References}

ANDREW, L.; HEATHER, G. Sensation seeking and tourism: tourist role, perception of risk and destination choice. Tourism Management, v. 29, p. 740-750, 2008.

ARBACHE, J. O mercado de trabalho na atividade econômica do turismo no Brasil. Brasília: Ed. Brasília, 2001.

BLAKE, A. et al. Tourism and poverty relief. Annals of Tourism Research, v. 35, n. 1, p. 107-126, 2008.

BROCKLESBY, M.; FISHER, E. Community development in sustainable livelihoods approaches: an introduction. Community Development Journal, v. 38, n. 3, p. 185-198, 2003.

BURNS, P.; HOLDEN, A. Tourism: a new perspective. London: Prentice Hall, 1995.

CARD, D.; KRUEGER, A. Minimum wages and employment: a case study of the fast-food industry in New Jersey and Pennsylvania. American Economic Review, v. 84, n. 4, p. 772-793, 1994.

COSTANZA, R.; DALY, H. Natural capital and sustainable development. Conservation Biology, v. 6, n. 1, p. 37-46, 1992.

COSTANZA, R. The value of the world's ecosystem services and natural capital. Nature 387, 253-259, 1997. 
CROES, R.; VANEGAS, M. Cointegration and causality between tourism and poverty reduction. Journal of Travel Researc, v. 47, p. 94-103, 2008.

DAVIES, T.; CAHILL, S. Environmental implications of the tourism industry. 2000. Web site: <www. rff.org/documents/rff-dp-00-14.pdf>.

DIXON, J. et al. Tourism and the environment in the Caribbean: an economic framework. 2001. Web site: <www-wds.worldbank.org/external/default/wdscontentserver/wdsp/ib/2001/09/28/000094946_ 01091904003762/rendered/pdf/multiOpage.pdf $>$.

HAWKINS, D.E.; MANN, S. The World Bank's role in tourism development. Annals of Tourism Research, v. 34, n. 2, p. 348-363, 2007.

HONG-BUMM, K. Perceived attractiveness Korean destinations. Annals of Tourism Research, v. 25, n. 2, p. 340-361, 1998.

KAKWANI, N.; NERI, M.; SON, H. Linkages between pro-poor growth, social programmes labour market: the recent Brazilian experience. World Development, v. 38, p. 881-884, 2010.

LOGAR, I. Sustainable Tourism Management in Crikvenica, Croatia: an assessment of policy instruments. Tourism Management, v. XXX, p. 1-11, 2009.

MATHIESON, A.; WALL, G. Tourism: economic, physical and social impacts. New York: Longman, 1986.

MENDONÇA JÚNIOR, E.P.; GARRIDO, I.M.D.A.; VASCONCELLOS, M.S.M. O turismo como fator de desenvolvimento socioeconômico da Costa do Descobrimento, Bahia, Brasil. Análise \& Dados — SEI, Salvador, v. 11, p. 118-124, 2001.

MEYER, B. Natural and quasi-experiments in economics. Journal of business and economic statistics, v. 13, n. 2, p. 151-161, 1995.

MINISTÉRIO DO TURISMO (MT). Turismo sustentável e alívio à pobreza no Brasil: reflexões e perspectivas. Brasília, 2005. p. 1-24. Web site: < http://institucional.turismo.gov.br/mintur/br/ministério/documentos/normas.cfm $>$.

MINISTÉRIO DO TURISMO (MT). Programa de Desenvolvimento do Turismo no Nordeste. Primeira fase. Relatório final de projeto. Banco do Nordeste. 2005. Web site: <www.bnb.gov.br/content/ aplicacao/prodetur/downloads/docs/docum9pcri.pdf $>$.

NERI, M. (Org.). Microcrédito, o mistério nordestino e o Grameen brasileiro. Rio de Janeiro: Editora da FGV, 2008.

NORTHCOTE, J.; MACBETH, J. Conceptualizing yield sustainable tourism management. Annals of Tourism Research, v. 33, n. 1, p. 199-220, 2006.

ORGANIZAÇÃO MUNDIAL DO TURISMO (OMT). Guia de desenvolvimento do turismo sustentável. Porto Alegre: Bookman, 2003.

PAPATHEODOROU, A. Why people travel to different places. Annals of tourism research, v. 28, n. 1, p. 164-179, 2001. 
RAVALLION, M. Evaluating anti-poverty programs. Handbook of development economics. Amsterdam, 2005.

SACHS, I. Estratégias de transição para o século XXI. In: BURSZTYN, M. (Org.). Para pensar o desenvolvimento sustentável. São Paulo: Brasiliense, 1993.

SIRAKAYA, Ercan; WOODSIDE, Arch G. Building and testing theories of decision making by travellers. Tourism Management, v. 26, n. 2, p. 815-832, 2005.

SWARBROOKE, J. Sustainable tourism management. Oxon: Cab International, 1999.

YILDIRIM, T.B. et al. Assessment of the natural-cultural resources in Canakkale for nature-based tourism. Environ Dev Sustain, v. 10, p. 871-881, 2008.

Marcelo Cortes Neri é professor da Escola de Pós-Graduação em Economia da Fundação Getulio Vargas (EPGE/FGV). E-mail: marcelo.neri@fgv.br.

Wagner Lopes Soares é pesquisador do Instituto Brasileiro de Geografia e Estatística (IBGE). E-mail: wagner.soares@ibge.gov.br. 